\section{Trusting the process and myself}

\author{
Emily Potter
}

I went to my first Canada Basketball National Team camp when I was 16 years old, which is an opportunity that I never thought would present itself. When I was in grade 9, I tried out for the provincial team (Basketball Manitoba), and the director sent my name to Canada Basketball. I hopped on a plane by myself, for the first time, with no idea what to expect. It was definitely a little overwhelming; I was out of my comfort zone, surrounded by people I didn't know. I just tried to be a sponge. I got cut from the team that first year, but the experience motivated me and opened my eyes to 1 day wearing the Canada jersey as an Olympian. I didn't think it was a possibility, and it never crossed my mind until I went to that first identification camp (figure 1 ).

We had lots of great off-court sessions about nutrition, recovery and mental health at that camp. It was the first time I realised that I needed to do more besides just play basketball when I got home. I went back to Winnipeg and was connected through Basketball Manitoba and Canada Basketball to a bunch of resources through the Centre for Sport Performance (eg, nutrition consultations, individual strength and conditioning three times a week). I also found a mental coach that I would see once every 1-2 weeks. I would just get really down on myself during games, so I needed to be able to cope with that better.

\section{DREAM DISRUPTED}

I enrolled at the University of Utah twoyears later. Other Canadians had attended the University of Utah, and their success internationally showed me that I could do the same thing. We had a couple ACL tears on my team my freshman year, so we did rehab before every workout, and worked on cutting and jumping to make sure our knees were stable. I was like, 'Okay, I'm passing all these things, doing good'. Then I was going for a layup, and it (an ACL rupture) still happened to me. I don't think I knew enough about why it happened or how it happened. I stayed in Utah for my (ACL reconstruction) surgery and rehabilitation, which was nearly a year. Being a student-athlete who suddenly has half the reason you are there stop for a year ... looking back I don't think I handled it very well. It's not like you have a manual, do you know what I mean? I was like, 'Oh my god, like I can't believe this. All I want to do is just play basketball'. When your heart hurts, that's what it felt like at first. I was just really, really sad. I remember when I first got injured, someone told me, 'You're going to be back better than ever'. I was so angry. I thought, 'Why would you ever say that? I wouldn't need to come back better if I wasn't hurt in the first place'. Sitting in on every practice and watching every game was really hard because I didn't want to be around basketball if I couldn't do it. Controlling my emotions about that was something I really needed to learn.
IT TAKES A VILLAGE

My family back in Canada were supersupportive. My sister and dad have both torn their ACLs. My sister tore her ACL in high school and returned to play Canadian university basketball, so she was definitely someone I could talk to about what I was going through. Canada Basketball was also supportive. I really wanted to come back and play that first summer after my injury. My surgeon was like, 'Well I can't tell you yes or no', so I went into training camp for a couple days, and the coaches said, 'No, you're not ready'. I'm glad that they did that. If I had been hurt when I was with Canada Basketball, then Utah would have been mad. I wanted to play, but I decided that I would go back to college, have a really good year and then Canada Basketball would call me back again.

Having a good surgeon with regular check-ins throughout my rehab had a positive impact on my ability to return 
to sport and stay healthy. The rehabilitation approach-where movements were broken down, rebuilt and remasteredreally helped. I remember the first time I did jumping; I was like, 'Wow, can I really do this?' You just kind of have to take that leap of faith, try it and you'll realise like, 'Yeah, I can do this'. I think the biggest lesson I learnt is to trust in myself. I did all that rehab, and coming back from that, you're scared. You get injured in a split second and it takes you 9 months to recover, so you don't want to go through that again. So, just trust in myself definitely is something that I've learnt from that and you can do it. Whatever situation you're thrown into, no matter what it is, you'll find a way out.

\section{WHOLE PICTURE}

I think a lot of physical things can be made worse if your mental health is suffering.
You may try to treat the physical, but the easiest way to a solution might be the mental aspect of things. I just think people need to be aware, look for changes on the mental side.

I definitely appreciated the professionals who will celebrate things with you. My teammates were there for the big milestones, like running for the first time, but I credit my athletic trainer a lot because she was with me every day, watching me do the small steps, taking the time to facilitate and celebrate the everyday good things I did. Athletes need to be able to communicate what they're feeling, but sports and exercise medicine professionals need to know how to get feelings out of them. My love has only grown for basketball since I started even through injury. I just love it and want to keep playing more.
Funding The author has not declared a specific grant for this research from any funding agency in the public, commercial or not-for-profit sectors.

Competing interests None declared.

Patient and public involvement Patients and/ or the public were involved in the design, conduct, reporting or dissemination plans of this research.

Patient consent for publication Obtained.

Provenance and peer review Commissioned; internally peer reviewed.

(c) Author(s) (or their employer(s)) 2021. No commercial re-use. See rights and permissions. Published by BMJ.

\section{(D) Check for updates}

To cite Potter E. Br J Sports Med 2021;55:349-350.

Accepted 3 June 2020

Published Online First 29 July 2020

Br J Sports Med 2021;55:349-350.

doi:10.1136/bjsports-2020-102431 